\title{
KEWENANGAN PEMERINTAH TERHADAP ORGANISASI OLAHRAGA PSSI
}

\author{
Yusup Suparman \\ Kepala Bagian Hukum dan Sekretaris Deputi IV \\ Bidang Peningkatan Prestasi Kemenpora \\ Email: ysuparman21@gmail.com,
}

\begin{abstract}
The existence of the PSSI organization in Indonesia has its own uniqueness. This uniqueness can be seen from their status as members of FIFA in the international world and as a sports organization that has the status as a legal entity in the country of Indonesia whose existence is a member of the Indonesian National Sports Committee (KONI).

In the concept of this scientific paper using the normative juridical research method. As well as using data collection techniques carried out using descriptive analysis techniques, with secondary data sources, which include primary legal materials such as laws and regulations relating to the statute and position of PSSI both in Koni membership and in FIFA membership. The PSSI statutes also explain the existence of PSSI as a member of FIFA, so the existence of the PSSI statute explains that the existence of PSSI in Indonesia is an independent organization and its existence as a member of FIFA, so that the regulations established by PSSI are based on rules made by FIFA. In Indonesia, PSSI is a sports organization, this existence is based on the provisions in Article 35 paragraph (1) of the Act No. 3 of 2005 concerning the National Sports System, namely "in sports management, the community can form a sports branch organization". However, the existence of sports organizations in Indonesia is also coordinated with the Indonesian National Sports Committee (KONI).
\end{abstract}

Keywords: PSSI, FIFA, Football, Government Authority

\section{PENDAHULUAN}

Sepak bola merupakan suatu bentuk olahraga yang sangat digemari di berbagai kalangan masyarakat di dunia ini, bahkan saat ini sepak bola sudah bukan lagi menjadi sekedar olahraga saja, melainkan sudah menjadi suatu bisnis global yang sangat berpengaruh dalam kehidupan masyarakat. Kompetisi sepak bola profesional sebagai salah satu cabang olahraga yang paling digemari di dunia memberikan sumbangan dan kesempatan yang sangat besar bagi pemajuan kesejahteraan umum, menurut Hinca Pandjaitan saat ini kesejahteraan umum tersebut tidak hanya terjadi di negara dimana kompetisi sepak bola itu dipertandingkan, tetapi juga di negara-negara yang membuat kompetisi sepak bola itu 


\section{(1)

menjadi komoditas ekonomi ${ }^{1}$. Contohnya adalah English Premiere League (Liga sepak bola profesional Inggris) dimana kompetisi itu hanya terjadi di negara inggris namun pengaruh bisnisnya meluas hingga negara-negara di luar Inggris, termasuk di Indonesia saat ini.

Berdasarkan perkembangan sepak bola di dunia tersebut maka dibentuklah suatu wadah yang bisa menyelenggarakan sepak bola secara internasional. Wadah tersebut berbentuk suatu badan federasi internasional yang bernama Federation Internationale de Football Association (FIFA). FIFA didirikan pada tahun 1904 dan bermarkas di Zurich, Swiss. Dalam fungsinya, FIFA mempunyai kewenangan penuh di bidang sepak bola di dunia ini, FIFA mempunyai fungsi seperti menyelenggarakan turnamen-turnamen internasional yang diikuti oleh negara-negara anggota dan FIFA jugalah yang membentuk peraturanperaturan yang terkait dengan sepak bola dan mengikat kepada seluruh anggota FIFA.

Dalam perkembangan sepak bola saat ini, kompetisi sepak bola banyak memberikan kesempatan kerja yang sangat besar bagi masyarakat, seperti pemain sepak bola, pengelola sepak bola, dan pihak-pihak lain yang ikut terlibat dalam bisnis sepak bola ini. Pada tahun 2006 saja sudah ada 270 juta orang aktif dalam sepak bola, yang terdiri atas 265 juta pemain laki-laki maupun perempuan dan 5 juta perangkat pertandingan yang bertugas menjalankan pertandingan sepak bola. Angka ini naik $10 \%$ dari survei yang dilakukan tahun 2000. Berdasarkan data tersebut juga, dari 85 juta pemain yang aktif di sepak bola Asia, ada 7.094.000pemain di Indonesia ${ }^{2}$.

Dengan adanya perkembangan sepak bola yang sangat pesat di Indonesia, maka sudah sewajarnya diperlukan suatu wadah yang menampung semua kegiatan yang berhubungan dengan sepak bola agar sepak bola bisa dimainkan dengan teratur dan profesional. Indonesia dimana sebagai anggota dari FIFA membentuk suatu wadah organisasi yang bergerak di bidang sepak bola yang disebut sebagai federasi sepak bola Indonesia atau disebut juga Persatuan Sepak Bola Seluruh Indonesia (PSSI) didirikan di Yogyakarta pada tanggal 19 April 1930, yang status badan hukumnya didaftarkan pada Departemen Kehakiman melalui Surat Keputusan Menteri Kehakiman Nomor J.A.5/11/b tanggal 2 Februari 1953, Berita Negara Republik Indonesia Nomor 18 tanggal 3 Maret $1953^{3}$. Sebagaimana dalam statuta PSSI disebut bahwa keberadaan PSSI merupakan anggota

\footnotetext{
${ }^{1}$ Hinca Pandjaitan, Kedaulatan Negara vs Kedaulatan FIFA Dalam Kompetisi Sepakbola Profesional untuk Memajukan Kesejahteraan Umum, PT Gramedia Pustaka Utama, Jakarta, 2011, hlm. 4. 


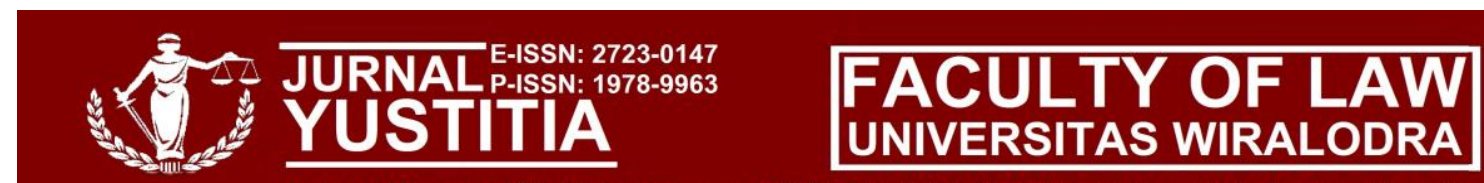

JI. Ir. H. Djuanda KM. 03 Indramayu 45213 Telp. 0234-275599 Email: yustitia.fh@unwir.ac.id

dari FIFA ${ }^{4}$ selaku organisasi sepak bola dunia, AFC selaku organisasi sepak bola di Asia ${ }^{5}$, AFF selaku organisasi sepak bola di Asia Tenggara. Oleh karena itu dalam pembentukan peraturan atau susunan organisasi, PSSI haruslah mengikuti ketentuan yang diatur di FIFA sehingga dalam perjalanannnya PSSI tidak boleh menyimpang dari peraturan yang dibuat oleh FIFA karena seperti yang dijelaskan di dalam Pasal 1 ayat (13) Surat keputusan Musyawarah Nasional Luar Biasa Persatuan Sepak Bola Seluruh Indonesia (MUNASLUB PSSI) Tahun 2009 "bahwa sepak bola merupakan permainan yang dikuasai dan dikontrol oleh FIFA"

Namun dalam perkembangannya, banyak hal-hal yang tidak sejalan dengan ketentuan yang ada di Article 17 statuta FIFA yang menyebutkan bahwa negara anggota haruslah independen terhadap tekanan dari pihak ketiga ${ }^{7}$. Namun saat kita melihat kisruh kasus sidang PSSI tahun lalu dimana pemerintah diawakilioleh Menteri Pemuda dan Olahraga mencoba untuk melakukan intervensi terhadap kongres yang diadakan oleh PSSI.

Kronologi kasus ini bermula saat kembali majunya Nurdin Halid sebagai calon ketua PSSI periode 2011-2015, gelombang protespun kian marak dilakukan. Hal ini tidak terlepas dari status dia sebagai mantan narapidana kasus korupsi. Efek dari kasus tersebut selain ada rasa tidak percaya dari para masyarakat dan hal ini bertentangan dengan statuta FIFA dimana calon ketua asosiasi sepak bola tidak boleh berstatuskan mantan narapidana. Kemudian kasus ini berkembang setelah calon lainnya George Toisutta dan Ariffin Panigoro ditolak oleh komite banding sebagai dua bakal calon ketua umum. PSSI akhirnya memutuskan untuk mengundurkan waktu pelaksanaan Kongres Pemilihan Ketua Umum Periode 2011-2015 yang sedianya akan dihelat 26 Maret mendatang di Bali. Alasan PSSI tersebut jelas terkait putusan Komite Banding yang menolak banding dua bakal calon Ketua umum George Toisutta dan Arifin Panigoro ${ }^{8}$.

Setelah semakin tidak jelasnya sidang PSSI tersebut, barulah Menteri Pemuda dan Olahraga Republik Indonesia mulai turut campur melihat ketidakjelasan kisruh sidang

4 Terdaftar di FIFA sejak tahun 1952 sebagaimana dinyatakan dalam Pasal 2 Statuta PSSI 2009

5 Terdaftar di AFC sejak tahun 1954 sebagaimana dinyatakan dalam Pasal 2 Statuta PSSI 2009

6 PSSI, Surat keputusan Musyawarah Nasional Luar Biasa Persatuan Sepak Bola Seluruh Indonesia Tahun 2009, ps. 1 ayat (13)

7 Article 17 (1) Statuta FIFA menyebutkan bahwa " Each Member shall manage its affairs independently and with no influence from thir parties"

8 Kisruh PSSI Masuk Agenda Sidang Konite Asosiasi FIFA, “http://sport.detik.com/sepakbola /read/2011/03/01/103953/1581818/76/kisruh-pssi-masuk-agenda-sidang-komiteasosiasi-fifa“"diunduh pada tanggal 21 February 2014 pada pukul 21.00 WIB 


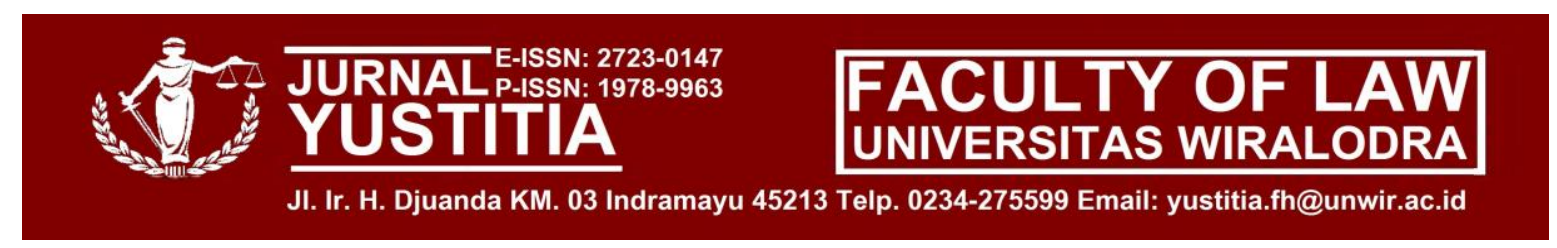

tersebut. tindakan pemerintah ini disertai dengan dasar hukum berdasarkan Peraturan Pemerintah Nomor 16 Tahun 2007 tentang Penyelenggaraan Keolahragaan, Pasal 118, yaitu "pengawasan dimaksud meliputi pengendalian internal dilakukan dengan cara memantau, mengevaluasi, dan menilai unsur kebijakan, prosedur, pengorganisasian, personil, perencanaan, penganggaran, pelaporan, dan supervisi dari penyelenggara kegiatan keolahragaan"9.

Dengan adanya kehendak dari Menteri Pemuda dan Olahraga Republik Indonesia untuk turut campur dalam kisruh internal PSSI ini menjadi perhatian khusus dari organisasi FIFA selaku organisasi induk sepak bola di seluruh dunia. Hal tersebut bisa dilihat dengan adanya teguran dari FIFA melalui surat eletronik kepada Suryadharma Tahir, Deputi Sekjen Bidang Luar Negri PSSI yang juga menjadi anggota komite etik FIFA. Teguran tersebut diberikan setelah adanya dugaan campur tangan pemerintah melalui Menteri Pemuda dan Olahraga Andi Mallarangeng ${ }^{10}$.

Federation Internationale de Football Association (FIFA), yang merupakan suatu federasi internasional yang bersifat independen. Keindependensian federasi tersebut juga berlaku terhadap anggotanya seperti yang dikemukakan di dalam peraturan PSSI itu sendiri, dimana keberadaan organisasi tersebut mempunyai mekanisme kerja sendiri dan bebas dari intervensi pihak manapun. Independensi PSSI sendiri juga dijelaskan di dalam Surat keputusan Musyawarah Nasional Luar Biasa Persatuan Sepak Bola Seluruh Indonesia (MUNASLUB PSSI) Tahun 2009 dengan Nomor: 02/MUNASLUB-PSSI/200911.

Keberadaan organisasi PSSI di Indonesia mempunyai keunikan sendiri. Keunikan itu dapat dilihat dari status mereka sebagai anggota FIFA di dunia Internasional dan sebagai organisasi olahraga yang berstatuskan sebagai badan hukum di negri Indonesia yang dimana keberadaannya merupakan sebagai anggota dari Komite Olahraga Nasional Indonesia (KONI). Di dalam statuta PSSI sendiri juga dijelaskan mengenai keberadaan PSSI sebagai

\footnotetext{
9 Menpora: PSSI Harus Tunduk Peraturan Pemerintah," http://isl-lovers.blogspot.com/2011/02/menporapssiharus-tunduk-peraturan.html", diunduh pada tanggal 10 Januari 2014 pada pukul $15.00 \mathrm{WIB}$

${ }^{10}$ PSSI Lolos Sanksi FIFA, "http://www.tempo.co/read/fokus/2011/03/02/1763/PSSI-Lolos-Sanksi- FIFA", diunduh pada tanggal 21 February 2015 pada pukul 21.10 WIB

${ }^{11}$ Dijelaskan dalam Pasal 2 ayat (2) yaitu PSSI adalah organisasi kemasyarakatan dan independen yang didirikan berdasarkan hukum dan perundang-undangan yang berlaku di Indonesia, terdaftar di Departemen Hukum dan Hak Asasi Manusia Republik Indonesia dan beromisili di Jakarta
} 


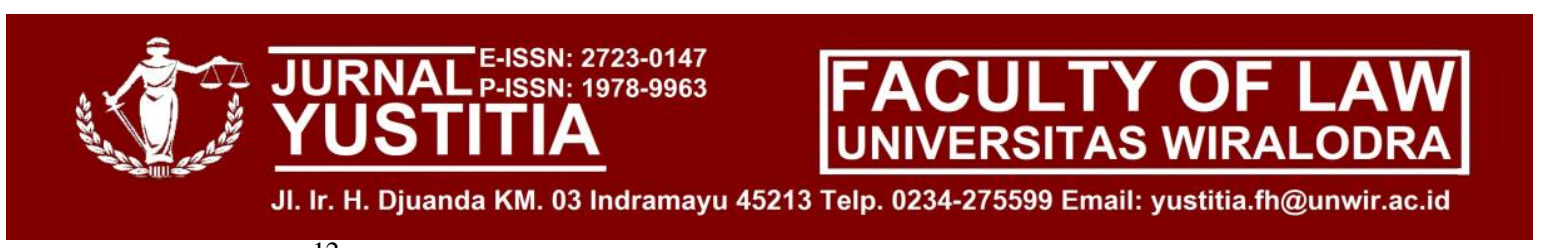

anggota dari FIFA ${ }^{12}$, sehingga dengan adanya keberadaan statuta PSSI tersebut menjelaskan bahwa keberadaan PSSI di Indonesia merupakan suatu organisasi yang bersifat independen dan keberadaannya sebagai anggota dari FIFA, sehingga peraturan-peraturan yang dibentuk oleh PSSI berdasarkan peraturan yang dibuat oleh FIFA. Di Indonesia, PSSI merupakan organisasi olahraga, keberadaan ini didasarkan pada ketentuan di dalam Pasal 35 ayat (1) Undang-Undang Republik Indonesia Nomor 3 Tahun 2005 tentang Sistem Keolahragaan Nasional yaitu "dalam pengelolaan keolahragaan, masyarakat dapat membentuk induk organisasi cabang olahraga". Namun keberadaan organisasi olahraga di Indonesia juga dikordinasi dengan adanya Komite Olahraga Nasional Indonesia (KONI). Seperti yang dijelaskan di dalam Pasal 36 ayat (1) UU No. 3 Tahun 2005 "Induk organisasi cabang olahraga sebagaimana dimaksud dalam Pasal 35 membentuk suatu komite olahraga nasional"". Dalam Pasal 36 ayat (4) UU No 3 Tahun 2005 "keberadaan komite tersebut berfungsi salah satunya sebagai mengkoordinasikan induk organisasi cabang olahraga, organisasi olahraga fungsional, serta komite olahraga provinsi dan komite olahraga kabupaten/kota"14.

Selain kedudukannya sebagai organisasi olahraga, bentuk dari pendirian PSSI adalah sebagai badan hukum ${ }^{15}$. Sehingga dengan statusnya sebagai badan hukum, menjadikan PSSI ini sebagai subjek hukum, dimana subjek hukum pada ranah hukum perdata adalah manusia dan badan hukum. Pada ranah hukum pidana, subyek hukumnya adalah manusia dan badan hukum $^{16}$. Subyek hukum sebagai pendukung hak dapat dikenakan kewajiban jika melakukan pelanggaran/kejahatan yang dilarang oleh peraturan perundang-undangan yang berlaku. Salah satu syarat keberadaan organisasi olahraga di Indonesia pada Pasal 47 ayat (4) Peraturan Pemerintah No. 16 Tahun 2007 tentang Penyelenggaraan Keolahragaan yaitu bahwa "setiap induk organisasi cabang olahraga dan induk organisasi fungsional yang memenuhi syarat sebagaimana dimaksud pada ayat (2) wajib menjadi anggota federasi

\footnotetext{
${ }^{12}$ Di dalam Article 1 (1) statuta FIFA disebutkan The Federation Internationale De Football Association (FIFA) is the only football federation in the world in which PSSI is member. It is hereafter referred to in these Statutes of PSSI as the FIFA.

${ }^{13}$ Republik Indonesia, Undang-Undang tentang Sistem Keolahragaan Nasional, UU No. 3 Tahun 2005, LN. No. 89 Tahun 2005, TLN. No. 4535, ps. 36 ayat (1)

${ }^{14}$ Pasal 36 ayat (4) Undang-Undang tentang Sistem Keolahragaan Nasional, UU No. 3 Tahun 2005

${ }^{15}$ Republik Indonesia, Peraturan Pemerintah tentang Penyelenggaraan Keolahragaan, PP No. 16 Tahun 2007, LN. No. 35 Tahun 2007, TLN. No. 4702, ps. 47 ayat (2)

${ }^{16} \mathrm{http}: / /$ www.hukumonline.com/klinik/detail/lt4f537a3a96a05/apa-arti-subyek-hukum-dan-subsider diunduh pada tanggal 26 April 2014 pada pukul $22.56 \mathrm{WIB}$
} 
olahraga internasional" ${ }^{17}$. Dalam PSSI, PSSI merupakan anggota federasi olahraga internasional yaitu Federation Internationale de Football Association (FIFA).

Di dalam statuta PSSI sendiri juga dijelaskan mengenai keberadaan PSSI sebagai anggota dari FIFA, sehingga dengan adanya keberadaan statuta PSSI tersebut menjelaskan bahwa keberadaan PSSI di Indonesia merupakan suatu organisasi yang bersifat independen dan keberadaannya sebagai anggota dari FIFA, sehingga peraturan-peraturan yang dibentuk oleh PSSI berdasarkan peraturan yang dibuat oleh FIFA. Hal inilah yang kerap kali menjadi pemicu permasalahan, karena seringkali adanya perbedaan pandangan yaitu PSSI sebagai organisasi olahraga nasional yang mengikuti ketentuan hukum di Indonesia dan Di dalam Article 1 (1) disebutkan The Federation Internationale De Football Association (FIFA) is the only football federation in the world in which PSSI is member. It is hereafter referred to in these Statutes of PSSI as the FIFA.

PSSI sebagai anggota FIFA yang mengikuti standar peraturan dari FIFA itu sendiri. Dalam konsep welfare state, tugas pemerintahan dalam negara hukum tidak saja untuk menjalankan pemerintahan, tetapi lebih dari itu harus meningkatkan kesejahteraan masyarakat dalam rangka mencapai tujuan negara ${ }^{18}$. Oleh karena itu, pemerintah sebuah negara hukum modern selain menjaga ketertiban dan keamanan, juga berfungsi untuk memajukan kesejahteraan rakyatnya ${ }^{19}$. Peningkatan kesejahteraan rakyat memiliki dimensi yang sangat luas, mencakup segala bidang kehidupan yang secara langsung maupun tidak langsung menyangkut harkat dan martabat manusia ${ }^{20}$, termasuk di bidang pengelolaan dan penyelenggaraan kompetisi sepak bola yang profesional yang sudah memasuki ruang global.

Hal inilah yang menjadi tujuan dalam penulisan ini, karena masalah PSSI ternyata tidak bisa dikategorikan mudah dari segi pengaturannya, dan terkait kedudukannya terhadap negara Indonesia maupun terhadap FIFA sebagai federasi induk dari organisasi PSSI ini juga banyak menimbulkan berbagai pendapat. Di dalam berbagai kalangan sendiri banyak muncul perdebatan terkait PSSI, ada yang mengatakan bahwa PSSI sebaiknya tidak bisa diintervensi negara, adapula yang mengatakan seharusnya PSSI tunduk pada hukum nasional negara kita.

\footnotetext{
${ }^{17}$ Pasal 47 ayat (4) Undang-Undang tentang Sistem Keolahragaan Nasional, UU No. 3 Tahun 2005.

${ }^{18}$ Hinca Pandjaitan, op cit, hlm. 29.

${ }^{19}$ Yudha Bhakti Ardhiwisastra, Hukum Internasional, Bunga Rampai, Alumni, Bandung, 2003, hlm. 57.

${ }^{20}$ Sondang Siagian, Administrasi Pembangunan, Konsep, Dimensi dan Strateginya, cet ke 4, Bumi Aksara, Jakarta, 2005, hlm. 138.
} 


\section{IDENTIFIKASI MASALAH}

Dari uraian di atas maka yang menjadi masalah dalam penelitian ini adalah sebagai berikut:

1. Bagaimana kedudukan negara terhadap organisasi PSSI sebagai organisasi olahraga?

2. Apa saja yang menjadi pertentangan antara sistem hukum olahraga nasional dengan sistem hukum FIFA?

\section{METODE}

Sifat penelitian dalam penulisan ini adalah deskriptif yang dilakukan dengan pendekatan yuridis normatif. Jenis dan sumber data yang digunakan adalah data sekunder. Pengumpulan data dilakukan terutama dengan teknik studi dokumen (library research and online research) dengan menginventarisasi data sekunder yang diperlukan, baik berupa bahan hukum primer, sekunder maupun tersier, kemudian melakukan penelusuran sejarahnya dan sinkronisasi antar bahan hukum tersebut. Bahan hukum primer yang dipergunakan terdiri dari peraturan perundang-undangan terutama yang berkaitan dengan program pengampunan pajak. Bahan hukum sekunder yang akan digunakan digunakan antara lain berupa: karya ilmiah, hasil penelitian dan literatur yang berkaitan dengan substansi penelitian. Bahan hukum tersier, yaitu bahan-bahan yang menunjang informasi bahan hukum primer dan sekunder, antara lain data dari surat kabar, jurnal, kamus, ensiklopedia.

\section{IV.HASIL DAN PEMBAHASAN}

\section{A. Kewenangan Eksekutif Terhadap Organisasi Olahraga di Indonesia}

a. Kewenangan Pemerintah pada Olahraga di Indonesia

Dalam menjalankan penyelenggaraan olahraga di Indonesia, suatu negara memerlukan peran dari pemerintah. Oleh karena itu, di dalam penulisan ini akan membahas bagaimana hukum nasional Indonesia memberikan kewenangan kepada pemerintah terhadap penyelenggaraan olahraga di Indonesia, selain itu juga dibahas bagaimana adanya pertentangan sistem hukum nasional dengan sistem hukum FIFA.

b. Kekuasaan Negara pada Umumnya

Dalam kenyataan bernegara kita harus sadari bahwa negara mempunyai kekuasaan yang sifatnya lain daripada kekuasaan yang dimiliki oleh organisasi yang terdapat dalam 


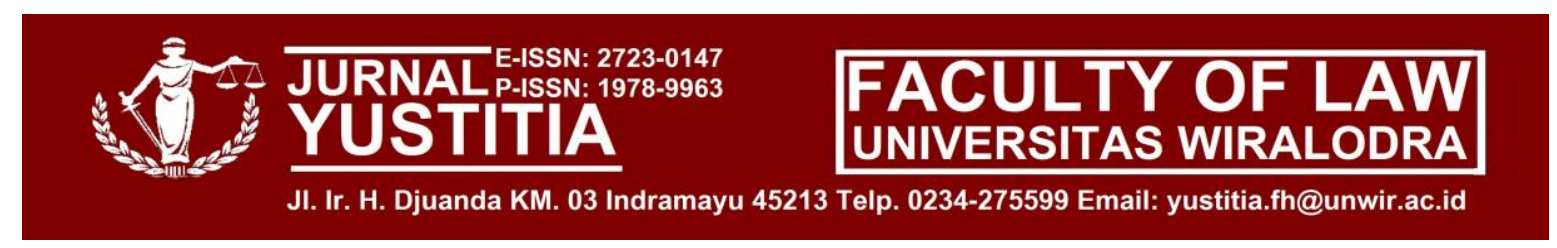

masyarakat. Berhubungan dengan kekuasaan negara, maka timbul suatu pertanyaan yaitu mengapa negara mempunyai kekuasaan seperti itu sedangkan organisasi yang ada di masyarakat tidak seperti itu. Untuk menjawab pertanyaan tersebut maka kita bisa melihat pendapat dari Max Weber, dia menyatakan bahwa hal tersebut disebabkan karena negara itu mempunyai "monopolie van het physieke geweld" (monopoli dalam menggunakan kekuasaan fisik) ${ }^{21}$.

Dalam teori perjanjian, disebutkan bahwa dalam mencari penghalalan bagi kekuasaan negara, dalam teori ini negara merupakan hasil perjanjian antara dua pihak dengan dua kepentingan yang berbeda, sehingga bersifat adanya hubungan timbal balik ${ }^{22}$. Rakyat sebagai pihak yang dikuasai, untuk melindungi hak miliknya mengadakan perjanjian dengan pihak penguasa. Sebagai imbalannya maka penguasa mempunyai sebab yang halal untuk mempunyai kekuasaan pada negara tersebut ${ }^{23}$.

Dalam perkembangan sejarah ketatanegaraan di dunia, kekuasaan negara dilakukan suatu pemisahan kekuasaan untuk mencegah adanya penyalahgunaan wewenang dari penguasa. Di zaman modern, konsep negara hukum di Eropa Kontinental dikembangkan antara lain oleh Julius Sthal, konsep negara hukum menurut Julius Sthal mencakup empat elemen penting, yaitu "Perlindungan hak asasi manusia, pembagian kekuasaan, pemerintah berdasarkan undang-undang, dan Peradilan Tata Usaha Negara"24.

Dari keempat elemen tersebut, kita melihat bahwa dalam suatu konsep negara hukum maka suatu pembagiaan kekuasaan perlu dilakukan. Di dalam prinsip pokok pemerintahan Presidensil yang bersifat universal, terdapat adanya pemisahan kekuasaan yang jelas antara cabang kekuasaan legislatif dan eksekutif ${ }^{25}$. Charles O. Jones menyatakan bahwa sistem pemisahaan kekuasaan dengan prinsip check and balances agar setiap kekuasaan bisa saling mengontrol dan mengimbangi satu sama lain ${ }^{26}$.

Dengan adanya pembagian kekuasaan seperti ini, menjadikan fungsi eksekutif yang benar-benar menjalankan undang-undang dalam kegiatan bernegara, karena fungsi eksekutif

\footnotetext{
${ }^{21}$ Max Weber sebagaimana dikutip di dalam C. T. Kansil dan Christine S.T Kansil, Hukum, Tata Negara Republik Indonesia 1 cet. Ke 3, PT Rineka Cipta, Jakarta, 2000, hlm. 73

${ }^{22}$ Tim Pengajar Mata Kuliah Ilmu Negara, Ilmu Negara, Fakultas Hukum Universitas Indonesia, Depok, 2008, hlm. 26

${ }^{23}$ Ibid

${ }^{24}$ Julius Stahl sebagaimana dikutip oleh Jimly Asshidiqie, Pokok-Pokok Hukum Tata Negara Indonesia (Pasca Reformasi), cet. Ke 2, PT Bhuana Ilmu Populer, Jakarta, 2008, hlm. 304.

25 ibid

${ }^{26} \mathrm{Ibid}$
} 


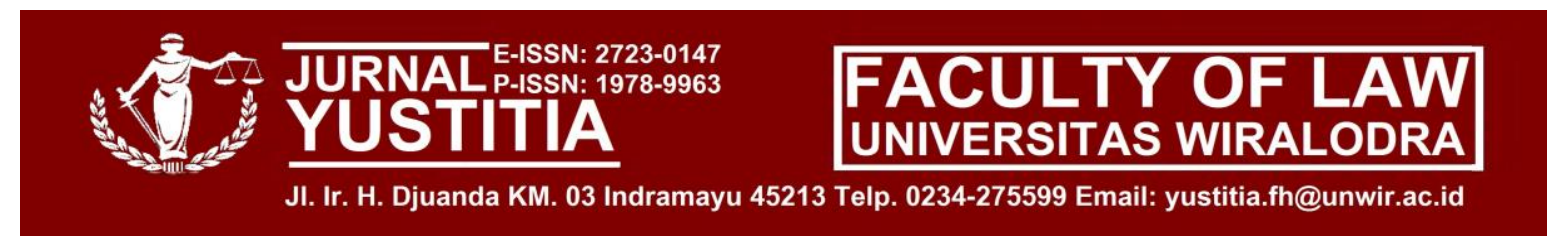

sendiri merupakan fungsi untuk melaksanakan undang-undang atau peraturan, dalam menjalankan fungsi eksekutif dilakukan oleh pemerintah dalam arti sempit ${ }^{27}$. Dalam UUD 1945, pada Pasal 4 ayat (1) disebutkan bahwa "Presiden Republik Indonesia memegang kekuasaan pemerintahan menurut Undang-Undang Dasar"28. Dari sini kita bisa lihat bahwa kekuasaan untuk menjalankan kegiatan pemerintahan di negara Republik Indonesia berada di tangan Presiden.

Ditinjau dari teori pemisahan kekuasaan, yang dimaksud kekuasaan pemerintahan adalah kekuasaan eksekutif. Sebagai kekuasaan eksekutif, penyelenggaraan pemerintahan yang dilaksanakan Presiden dapat dibedakan antara kekuasan penyelenggaraan yang bersifat umum dan kekuasaan penyelenggaraan pemerintahan yang bersifat khusus ${ }^{29}$. Dalam konteks kekuasaan penyelenggaraan yang bersifat umum adalah kekuasaan menyelenggarakan administrasi negara. Presiden adalah pimpinan tertinggi penyelenggaraan administrasi negara. Penyelenggaraan administrasi negara meliputi lingkup tugas dan wewenang yang sangat luas, yaitu setiap bentuk perbuatan atau kegiatan administrasi negara. Tugas dan wewenang tersebut dapat di kelompokkan ke dalam beberapa golongan: ${ }^{30}$

1) Tugas dan wewenang administrasi di bidang keamanan dan ketertiban umum. Dalam konteks penulisan ini, bidang keamanan dan ketertiban umum berkaitan dengan kesejahteraan umum, yaitu pemerintah melakukan tugas dan wewenangnya di dalam bidang keamana dan ketertiban umum agar kesejahteraan umum dapat tercapai di Indonesia.

2) Tugas dan wewenang menyelenggarakan tata usaha pemerintahan mulai dari surat menyurat sampai kepada dokumentasi dan lain-lain. Dalam tugas dan wewenang ini, pemerintah mempunyai tugas dan wewenang dalam mengurusi masalah administratif pemerintahan.

3) Tugas dan wewenang administrasi negara di bidang pelayanan umum. Dalam tugas dan wewenang ini, pemerintah bertugas untuk menyediakan sarana dan prasarana bagi warganya agar warganya bisa melakukan aktifitas bermasyarakat.

\footnotetext{
27 Jimly Asshidiqqie, Pergumulan Peran Pemerintah dan Parlemen Dalam Sejarah (Telaah Perbandingan Konstitusi Berbagai Negara), UI-Press, Jakarta, 1996, hlm. 3.

${ }^{28}$ Republik Indonesia, Undang-Undang Dasar Republik Indonesia, amandemen ke empat, ps. 4 ayat (1)

${ }^{29}$ Bagir Manan, Lembaga Kepresidenan, cet. Ke 2, FH UII Press, Yogyakarta, 2003, hlm. 122.

30 Ibid
} 
4) Tugas dan wewenang administrasi negara di bidang penyelenggaraan kesejahteraan umum.Dalam hal ini pemerintah mempunyai suatu kewajiban untuk memajukan kesejahteraan umum dan memaksimalkan kesejahteraan sosial

c. Kewenangan Pemerintah di Indonesia Dalam Bidang Olahraga

Penyelenggaraan olahraga di Indonesia awalnya hanya dilakukan oleh PSSI selaku organisasi olahraga sepak bola di Indonesia, namun dalam perkembangannya seperti yang dijelaskan di dalam bab sebelumnya, negara merasa perlu ikut turun tangan dalam kegiatan penyelenggaraan sepak bola di negara ini. Dalam pembahasan mengenai kekuasaan negara, dijelaskan bahwa wewenang pemerintah adalah dalam menyelenggarakan kesejahteraan umum, sehingga dalam hal ini negara mempunyai suatu kewajiban untuk memajukan kesejahteraan umum dan memaksimalkan kesejahteraan sosial. Dalam melaksanakan tujuan tersebut, negara tidak dapat mengingkari dirinya sebagai bagian dari masyarakat dunia yang bergerak dinamis. Globalisasi menjadi suatu keniscayaan dan karenanya mendorong inovasi dan kreativitas negara untuk memajukan kesejahteraan umum ${ }^{31}$, seperti apa yang dikatakan oleh Vicente Fox: ${ }^{32}$ state must now have a firm structure with the capacity to change and respond; a structure that will promote new forms of production, participation, education, and peaceful coexcistence. It is time for innovation, for building new and better decisionmaking capabilities, and for consolidating and ensuring stability and the effective of our democraties. In brief, the state could be able to generate and ensure the conditions that allow us to join in and remain part of world development in the most effective manner possible.

Di Indonesia, tujuan negara dalam hubungannya dengan tujuan negara hukum, adalah negara kesejahteraan (welfare state), maka peran dan posisi negara secara terus menerus tanpa henti melakukan upaya untuk memajukan kesejahteraan warga negaranya ${ }^{33}$. Negara Kesatuan Republik Indonesia didirikan sebagai negara kesejahteraan, sebagaimana dirumuskan dalam alinea keempat Pembukaan UUD 1945, sebagai berikut: Kemudian daripada itu untuk membentuk suatu pemerintah negara Indonesia yang melindungi segenap bangsa Indonesia dan seluruh tumpah darah Indonesia dan untuk memajukan kesejahteraan umum, mencerdaskan kehidupan bangsa, dan ikut melaksanakan ketertiban dunia yang

\footnotetext{
${ }^{31}$ Hinca Pandjaitan, op cit, hlm. 1

${ }^{32}$ Ibid, hlm 1-2

${ }^{33}$ Ibid, hlm 8
} 


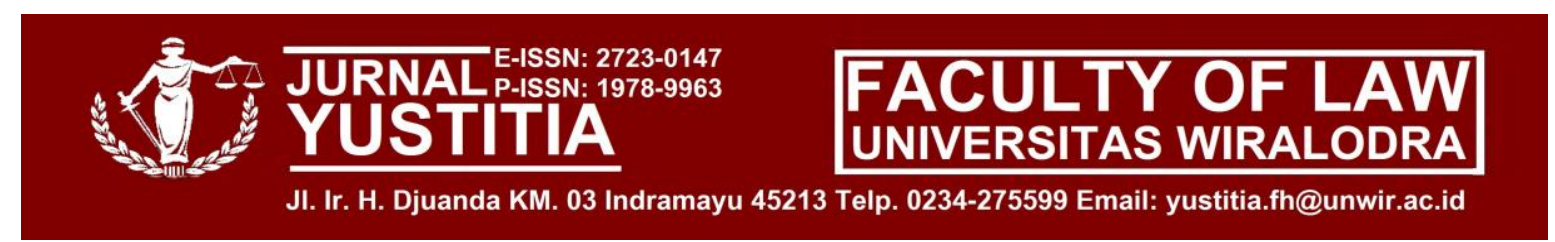

berdasarkan kemerdekaan, perdamaian abadi dan keadilan sosial, maka disusunlah kemerdekaan kebangsaan Indonesia itu dalam suatu Undang- Undang Dasar negara Indonesia, yang terbentuk dalam suatu susunan negara Republik Indonesia yang berkedaulatan rakyat dengan berdasar kepada : Ketuhanan Yang Maha Esa, kemanusiaan yang adil dan beradab, persatuan Indonesia, dan kerakyatan yang dipimpin oleh hikmat kebijaksanaan dalam permusyawaratan/perwakilan, serta dengan mewujudkan suatu keadilan sosial bagi seluruh rakyat Indonesia.

Dalam menjalankan kegiatan negaranya, pemerintah Republik Indonesia dalam menjalankan fungsi pemerintahan mempunyai tugas untuk memajukan kesejahteraan umum di Indonesia dalam rangka mencapai tujuan negara seperti yang dituangkan di Pembukaan UUD 1945 tersebut. Namun, kesejahteraan umum disini mempunyai pengertian yang luas, karena kesejahteraan tidak melulu bersifat materi saja, namun juga mencakup segala bidang kehidupan manusia, termasuk di penyelenggaraan sepak bola. Memajukan kesejahteraan umum mengharuskan terjaminnya keseluruhan prasyarat sosial yang memungkinkan atau mempermudah manusia untuk mengembangkan semua nilainya, atau sebagai penjumlahan semua kondisi kehidupan sosial yang diperlukan agar masing-masing individu, keluargakeluarga, dan kelompok-kelompok masyarakat dapat mencapai keutuhan atau perkembangan mereka dengan lebih utuh dan cepat ${ }^{34}$. Keadilan sosial yang dimaksudkan adalah dalam kerangka Pancasila, yang menurut Purbadi Purbacaraka dan Soerjono Soekanto merupakan perumusan terarah pada tujuan setiap pribadi manusia yaitu keserasian rohaniah dan jasmaniah, termasuk berolahraga ${ }^{35}$.

Dalam hal memajukan kesejahteraan umum ini, maka pemerintah selaku pemegang kekuasaan eksekutif mempunyai tugas dan wewenangnya di bidang olahraga dalam rangka untuk memajukan kesejahteraan umum. Selain itu, pemerintah juga mempunyai tugas dan wewenang di bidang pelayanan umum, sehingga disini pemerintah berfungsi untuk menciptakan syarat dan kondisi serta infrastruktur yang harus tersedia bagi warga negaranya untuk mempunyai akses yang cukup untuk dalam kegiatan berolahrga. Sehingga disini pemerintah dibentuk bukan untuk menciptakan kesejahteraan umum, melainkan untuk memajukan kesejahteraan umum.

\footnotetext{
34 Ibid

${ }^{35}$ Purnadi Purbacaraka dan Soerjono Soekanto, Renungan Tentang Filsafat Hukum, Rajawali, Jakarta, 1982, hlm. 87-88
} 
d. Kewenangan Menteri Pemuda dan Olahraga

Menteri merupakan jabatan politik, dalam tugas-tugasnya sebagai pejabat politik, menteri melakukan pengambilan keputusan dalam menentukan suatu kebijakan. Dalam Pasal 17 UUD 1945 dijelaskan bahwa:

(1) Presiden dibantu oleh menteri-menteri negara

(2) Menteri-menteri itu diangkat dan diberhentikan oleh Presiden.

(3) Setiap menteri membidangi urusan tertentu dalam pemerintahan.

(4) Pembentukan, pengubahan, dan pembubaran kementerian negara diatur dalam undang-undang.

Dalam Penjelasan UUD 1945 yang sekarang hanya berlaku sebagai dokumen historis, tercantum uraian bahwa jabatan menteri itu merupakan jabatan yang sangat penting. Menteri adalah pejabat tinggi yang secara nyata bertindak sebagai pemimpin pemerintahan sehari-hari dalam bidangnya masing-masing. Tentang istilah menteri negara, terdapat kebiasaan untuk mengartikan seolah menteri negara itu adalah menteri yang tidak memimpin departemen.n Namun, dalam rumusan ketentuan Pasal 17 ayat (1) dan bahkan dalam judul bab V UUD 1945 jelas dipakai istilah menteri negara dan kementerian negara untuk untuk pengertian yang bersifat umum dan berlaku untuk semua menteri ${ }^{36}$. Posisi Menteri Pemuda dan Olahraga Republik Indonesia adalah sebagai menteri yang mewakili pemerintah dalam bidang kepemudaan dan olahraga. Pemberian kewenangan kepada Menteri Pemuda dan Olahraga melalui pasal 4 Undang-Undang Nomor 39 Tahun 2008 tentang Kementerian Negara, yaitu:

(1) Setiap Menteri membidangi urusan tertentu dalam pemerintahan.

(2) Urusan tertentu dalam pemerintahan sebagaimana dimaksud pada ayat (1) terdiri atas:

a) urusan pemerintahan yang nomenklatur Kementeriannya secara tegas disebutkan dalam Undang-Undang Dasar Negara Republik Indonesia Tahun 1945

b) urusan pemerintahan yang ruang lingkupnya disebutkan dalam Undang-Undang Dasar Negara Republik Indonesia Tahun 1945; dan

c) urusan pemerintahan dalam rangka penajaman, koordinasi, dan sinkronisasi program pemerintah.

\footnotetext{
${ }^{36}$ Jimly Asshidiqie, Pokok-Pokok Hukum Tata Negara Indonesia (Pasca Reformasi), op cit, hlm. 369.
} 
Di dalam pasal 5 UU Nomor 39 Tahun 2008 tentang Kementerian Negara disebutkan bahwa urusan pemerintahan dalam poin c meliputi urusan perencanaan pembangunan nasional, aparatur negara, kesekretariatan negara, badan usaha milik negara, pertanahan, kependudukan, lingkungan hidup, ilmu pengetahuan, teknologi, investasi, koperasi, usaha kecil dan menengah, pariwisata, pemberdayaan perempuan, pemuda, olahraga. Sehingga dengan ketentuan di dalam undang-undang ini maka kewenangan dalam penyelenggaraan olahraga diberikan kepada menteri yang membidangi urusan olahraga, yaitu Menteri Pemuda dan Olahraga Republik Indonesia.

Dengan diberikannya kewenangan dalam penyelenggaraan olahraga kepada Menteri, maka diperlukan suatu pengaturan yang berbentuk undang- dalam undang-undang tersebut perlu dijelaskan tugas dan wewenanga menteri dalam menyelenggarakan olahraga di Indonesia. Undang-Undang yang mengatur kewenangan dan tugas menteri adalah UndangUndang No. 3 tahun 2005 tentang Sistem Keolahragaan Nasional Kewenangan Menteri Pemuda dan Olahraga dalam penyelenggaraan keolahragaan diatur di dalam Pasal 14 ayat (1) Undang-Undang No. 3 tahun 2005 tentang Sistem Keolahragaan Nasional yaitu "Pelaksanaaan tugas penyelenggaraan keolahragaan sebagaimana dimaksud dalam Pasal 13 pada tingkat nasional dilakukan secara terpadu dan berkesinambungan yang dikoordinasikan oleh menteri”

Dalam Pasal 13 Undang-Undang No. 3 Tahun 2005 tersebut, dijelaskan mengenai apa yang menjadi kewenangan Menteri Pemuda dan Olahraga, yaitu "Pemerintah mempunyai kewenangan untuk mengatur, membina, mengembangkan, melaksanakan, dan mengawasi penyelenggaraan keolahragaan secara nasional.” Dalam Pasal 2 Peraturan Pemerintah No. 16 Tahun 2007 tentang Penyelenggaraan Keolahragaan mengatur mengenai tugas pemerintah dalam penyelenggaraan keolahragaan, yaitu

(1) Pemerintah menentukan kebijakan nasional keolahragaan, standar nasional keolahragaan, serta koordinasi dan pengawasan terhadap penyelenggaraan keolahragaan nasional.

(2) Penentuan kebijakan nasional keolahragaan, standar nasional keolahragaan, serta koordinasi dan pengawasan terhadap penyelenggaraan keolahragaan nasional sebagaimana dimaksud pada ayat (1) menjadi tanggung jawab Menteri.

Oleh karena itu berdasarkan penjelasan diatas tersebut maka dapat disimpulkan bahwa Menteri Pemuda dan Olahraga Republik Indonesia bertindak sebagai wakil dari 


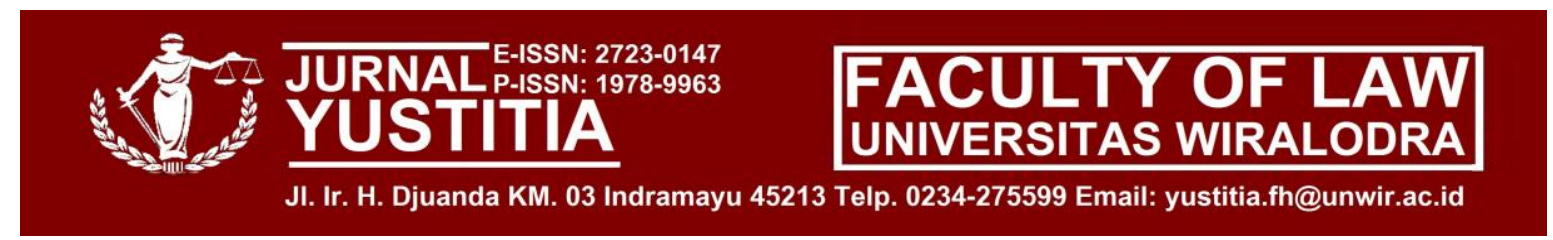

pemerintah dalam masalah penyelenggaraan olahraga di Indonesia. Mengenai tugas dan wewenangnya, diatur di dalam Undang-Undang No. 3 tahun 2005 tentang Sistem Keolahragaan Nasional dan Peraturan Pemerintah No. 16 Tahun 2007 tentang Penyelenggaraan Keolahragaan.

e. Perbandingan Antara Sistem Hukum Olahraga Nasional dengan Sistem Hukum FIFA

Sebelum kita membahas lebih lanjut, pertama kita harus mengetahui adanya sistem hukum olahraga nasional, yaitu adalah domestic sports law dan national sports law. Dalam sistem hukum ini terdapat perbedaan yang mencolok yaitu bahwa dalam domestic sports law, dimana hukum olahraga itu berasal dari organisasi olahraga nasional. Sedangkan national sports law adalah hukum olahraga yang berasal dari undang-undang yang dibentuk oleh suatu negara.

Dalam praktiknya Indonesia lebih memilih menggunakan sistem hukum national sports law, hal ini bisa dilihat dengan dibentuknya Undang-Undang No. 3 Tahun 2005 tentang Sistem Keolahragaan Nasional. Sedangkan di dalah hukum transnasional olahraga, seperti yang dijelaskan di dalam bab sebelumnya, kita mengenal adanya Lex Sportiva dan Lex Ludica. Lex Ludica adalah sebagian dari subsitem dari Lex Sportiva yakni sebagai the Laws of the Game, sedangkan Lex Sportiva adalah sistem hukum FIFA secara keseluruhan dalam mengatur, mengelola, melaksanakan, dan menyelesaikan sengketa dalam kompetisi sepak bola profesional ${ }^{37}$. Keberadaan Lex Ludica itu sangatlah kuat dan tidak bisa diintervensi serta merta oleh negara. Hal ini bisa terjadi karena Lex Ludica itu sama sekali tidak dibuat oleh negara, melainkan dibuat dan diciptakan oleh international society.

Berbeda dengan Lex Ludica, maka Lex Sportiva mempunyai titik singgung dengan sistem hukum suatu negara dimana kompetisi sepak bola bisa berjalan karena adanya intervensi negara, tetapi intervensi di sini berada di dalam konteks yang strategis dan sesuai dengan kompetensinya dengan satu tujuan untuk memastikan kompetisi sepak bola profesional itu dapat berjalan sesuai dengan sistem hukum dan mekanismenya sendiri ${ }^{38}$.

Dalam penulisan ini terdapat perbedaan pandangan berupa adanya perbedaan pandangan yang dimana pada satu pihak lebih mengutamakan keberlakuan sistem hukum FIFA dan di pihak lain lebih mengutamakan bahwa di negara ini lebih diutamakan adalah

\footnotetext{
${ }^{37}$ Hinca Pandjaitan, op cit, hlm. 217

38 Ibid
} 


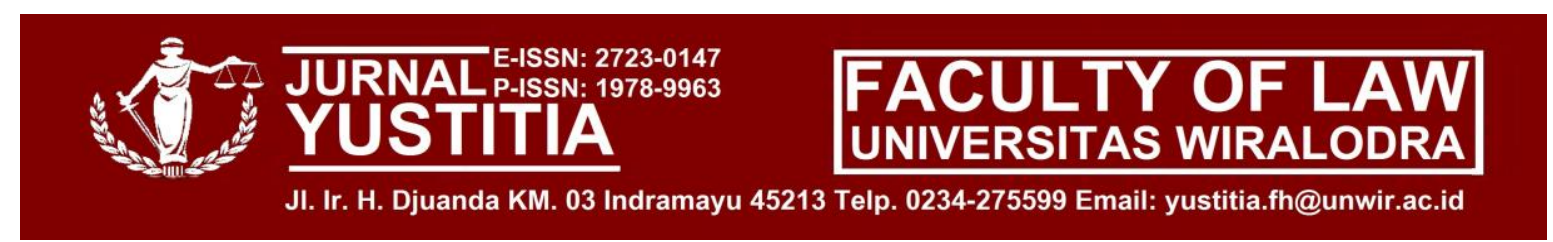

keberlakuan hukum nasional. Oleh karena itu, dalam pembahasan penelitian ini akan membahas mengenai adanya suatu harmonisasi keberadaan pluralisme hukum dimana keberadaan hukum nasional dan hukum transnasional dicoba untuk dicari suatu titik singgungnya agar bisa ditemukan jawaban dari permasalahan dalam penelitian ini. Dalam perbandingan antara sistem hukum olahraga ini akan memperbandingan antara sistem hukum olahraga nasional dan sistem hukum olahraga transnasional. Dalam sistem hukum olahraga nasional di negara Indonesia, terdapat dua sistem hukum yang berlaku yaitu domestic sports law dan national sports law. Dalam sistem hukum domestic sports law di negara ini dibentuk oleh organisasi olahraga nasional yang dimana di dalam penulisan ini adalah peraturan yang berasal dari organisasi Persatuan Sepakbola Seluruh Indonesia.

Dalam domestic sports law di negara kita tidak terdapat permasalahan hukum dengan sistem hukum olahraga transnasional yang dimana dalam penulisan ini adalah peraturan yang dibentuk oleh FIFA, karena dalam sistem hukum yang dibentuk PSSI dibentuk berdasarkan standar dari statuta FIFA. Walaupun memang antara sistem hukum PSSI dan sistem hukum FIFA memang terdapat pertentangan pengaturan, hal tersebut bukanlah menjadi kewenangan pemerintah untuk ikut campur tangan, karena seperti yang dijelaskan dalam bab sebelumnya bahwa PSSI dibentuk bukan berdasarkan keinginan pemerintah melainkan dari adanya kehendak masyarakat dan status PSSI sendiri di Indonesia bukanlah bagian dari pemerintah, melainkan organisasi olahraga yang dibentuk oleh masyarakat yang bersifat independen, sehingga hubungan antara pemerintah dengan PSSI bukanlah hubungan vertikal melainkan suatu hubungan horizontal. Oleh karena itu di dalam penulisan ini tidak akan dibahas mengenai perbandingan antara sistem hukum FIFA dengan sistem hukum PSSI (domestic sports law).

Sehingga dalam tulisan ini akan dibahas mengenai adanya pertentangan antara national sports law dengan sistem hukum FIFA. Dalam bentuk hukum national sports law yaitu Undang-Undang No. 3 Tahun 2005 tentang Sistem Keolahragaan Nasional dan Peraturan Pemerintah Nomor 16 Tahun 2007 tentang Penyelenggaraan Keolahragaan terdapat pertentangan dengan sistem hukum dari FIFA. Mengenai sistem hukum Lex Ludica tidak akan dibahas di dalam penulisan ini karena dalam Undang-Undang Nomor 3 Tahun 2005 dan Peraturan Pemerintah Nomor 16 Tahun 2007 tidaklah mengatur bagaimana Laws of the Game dari sepak bola, karena dalam kedua produk hukum tersebut adalah untuk mengatur mengenai penyelenggaraan sepakbola di Indonesia, sehingga kedua produk hukum 
ini akan coba diperbandingkan dengan Lex Sportiva dari statuta FIFA agar hasilnya bisa diharmonisasi.

Apabila dilihat dari sistem hukum nasional negara ini, akan terlihat bagaimana adanya upaya intervensi yang dilakukan pemerintah terhadap penyelenggaraan olahraga di negara ini. Apabila dilihat bagaimana kisruhnya pemilihan Ketua Umum Periode 20112015, disana terlihat bagaimana pemerintah berupaya untuk campur tangan dengan menggunakan dasar hukum Pasal 118 Peraturan Pemerintah Nomor 16 Tahun 2007 tentang Penyelenggaraan Keolahragaan. Pengawasan yang dimaksud meliputi pengendalian internal dilakukan dengan cara memantau, mengevaluasi, dan menilai unsur kebijakan, prosedur, pengorganisasian, personil, perencanaan, penganggaran, pelaporan dan supervisi dari penyelenggara kegiatan keolahragaan.

Dari sini terlihat adanya pertentangan antara hukum olahraga nasional negara kita dengan hukum dari statuta FIFA bahkan kejadian ini memperlihatkan bagaimana pemerintah tidak menghormati organisasi-organisasi yang hidup di masyarakat bahkan status hukum organisasi tersebut merupakan sebagai badan hukum di Indonesia. Di dalam statuta FIFA tahun 2010 dijelaskan pada Pasal 17 ayat (1) Statuta FIFA bahwa "Each Member shall manage its affairs independently and with no influence from thir parties" ${ }^{39}$. Sehingga dalam hal ini, sistem hukum olahraga nasional negara tidak sesuai dengan ketentuan hukum yang dibuat oleh FIFA selaku pemilik otoritas untuk menyelenggarakan kegiatan sepak bola secara internasional.

Ketentuan Pasal 118 Peraturan Pemerintah Nomor 16 Tahun 2007 yang memperlihatkan bagaimana adanya celah pemerintah untuk bisa campur tangan terhadap organisasi olahraga yang ada bertentangan dengan ketentuan hukum yang ada di Peraturan Pemerintah tersebut, karena di dalam Peraturan Pemerintah tersebut dijelaskan di dalam Pasal 47 ayat (4) bahwa "setiap induk organisasi cabang olahraga dan induk organisasi olahraga fungsional yang memenuhi syarat sebagaimana dimaksud pada ayat (2) wajib menjadi anggota federasi olahraga internasional”. Sehingga dari sini dapat terlihat adanya pengakuan pemerintah terhadap kedudukan suatu federasi olahraga internasional, sehingga dari sini bisa dilihat bahwa sistem hukum olahraga nasional yang ada di negara Indonesia berhubungan dengan sistem hukum dari federasi olahraga internasional yang ada. Sehingga

\footnotetext{
${ }^{39}$ FIFA, Statuta FIFA 2010 Edition, ps. 17 ayat (1)
} 
apabila ada pertentangan antara kedua sistem hukum tersebut maka harus ditentukan adanya harmonisasi agar kedua sistem hukum tersebut bisa berjalan baik sehingga hasilnya penyelenggaraan olahraga bisa berjalan dengan baik.

\section{B. Intervensi Pemerintah pada Organisasi Olahraga}

Dalam praktik penyelenggaraan olahraga, pada perkembangannya terdapat adanya upaya-upaya intervensi yang dilakukan pemerintah. Hal ini tidak lepas dari adanya UndangUndang tentang Sistem Keolahragaan Nasional dan Peraturan Pemerintah tentang Penyelenggaraan Keolahragaan, karena dari kedua produk hukum tersebut memungkinkan adanya celah bagi pemerintah untuk melakukan suatu intervensi terhadap keberadaan PSSI.

a. Pengertian Intervensi pada Umumnya

Intervensi dalam penulisan ini adalah mengenai intervensi negara dalam rangka memajukan kesejahteraan umum dalam era globalisasi ini. Intervensi dapat diartikan sebagai keterlibatan suatu negara dengan cara kekuatan dalam masalah negara lain untuk mempengaruhi kebijakan internal dan eksternal negara yang diintervensi tersebut ${ }^{40}$. Menurut Hinca Pandjaitan, pengertian dan prinsip dasar non intervention juga dapat diberlakukan terhadap organ non negara, yaitu lembaga internasional yang juga mempunyai sistem hukumnya sendiri. Intervensi dalam kamus besar bahasa Indonesia disebutkan sebagai campur tangan di antara perselisihan dua pihak, sehingga apabila dikaitkan dengan penulisan ini akan disebutkan bahwa suatu intervensi adalah suatu upaya campur tangan pemerintah terhadap adanya suatu perselisihan yang terjadi di dalam penyelenggaraan olahraga.

Dalam pengertian intervensi ini, kita bisa simpulkan bahwa intervensi tidak selamanya berkonotasi negatif karena pengertian dari intervensi sendiri bisa juga bermakna positif tergantung dari niat dan tujuannya. Dalam suatu kehidupan bernegara, intervensi negara pasti akan terjadi, namun yang menjadi pertanyaannya adalah bagaimana negara secara sadar melakukan intervensi secara strategis untuk menciptakan kondisi kehidupan bermasyarakat yang baik dan teratur.

Dalam upaya negara untuk memajukan kesejahteraan umum, yang perlu diperhatikan negara adalah adanya arus globalisasi saat ini. Tidak bisa kita pungkiri bahwa globalisasi harus bisa diterima di dalam kehidupan bernegara, namun dalam masalah ini negara harus bisa memainkan perannya sebagai negara yang memegang kedaulatan suatu negara tersebut

\footnotetext{
${ }^{40}$ Hinca Pandjaitan, op cit, hlm. 113.
} 
agar bisa menempatkan diri di posisi yang tepat dalam arus globalisasi saat ini. Dalam upayanya memajukan kesejahteraan umum, negara harus bisa memastikan kerja samanya antara negara dan warganegaranya yang sering disebut civil society.

Hal ini selaras dengan teori Hegel tentang negara dalam arti civil society sebagaimana telah diuraikan sebelumnya. Globalization calls building robust partnerships, however, can only emerge between an intelligent, democratic state and a vibrant civil society. Globalization requires improved channels of participation. The need continues to grow for greater citizen participation and new participatory policymaking. In particular, the state could greatly benefit from weaving stronger social networks. It has been common to see important social and economic problems in developing countries as the exclusive responsibility of the state when, in reality, they might be more effectively solved by civil society or the market ${ }^{41}$. Sesungguhnya globalisasi dapat melahirkan dua kemungkinan, yaitu bisa bermanfaat bagi kesejahteraan umum atau juga bisa jadi sebaliknya. Oleh karena itu globalisasi harus bisa dimanfaatkan bagi suatu negara dalam melakukan intervensi strategis yang sesuai dengan kompetensinya.

b. Intervensi Pemerintah di Dalam Undang-Undang Nomor 3 Tahun 2005 tentang Sistem Keolahragaan Nasional

Alasan adanya pembentukan Undang-Undang Nomor 3 Tahun 2005 tentang Sistem Keolahragaan Nasional adalah berdasarkan pada Pembukaan UUD 1945, dengan mengutip secara utuh bunyi kalimat alinea keempat Pembukaan UUD 1945, yaitu Kemudian daripada itu untuk membentuk suatu pemerintah negara Indonesia yang melindungi segenap bangsa Indonesia dan seluruh tumpah darah Indonesia dan untuk memajukan kesejahteraan umum, mencerdaskan kehidupan bangsa, dan ikut melaksanakan ketertiban dunia yang berdasarkan kemerdekaan, perdamaian abadi dan keadilan sosial

Bahwa dalam rangka mengisi kemerdekaan dan mewujudkan kesejahteraan umum itulah sehingga diperlukan upaya mewujudkan kehidupan bangsa yang bermanfaat bagi pembangunan yang berkeadilan dan demokratis secara bertahap dan berkesinambungan. Intervensi dalam arti campur tangan dilakukan negara secara terang dapat dilihat dalam batang tubuh Undang-Undang Nomor 3 Tahun 2005 tentang Sistem Keolahragaan Nasional dan ketiga Peraturan Pemerintah sebagai peraturan pelaksanaanya, dengan cara

\footnotetext{
${ }^{41}$ Hinca Pandjaitan, op cit, hlm. 117.
} 
melimpahkannya dari state kepada menteri yang bertanggung jawab dalam bidang keolahragaan di level nasional, sedangkan di level daerah dilakukan oleh pemerintah daerah yaitu gubernur di level propinsi dan bupati atau walikota di level Kabupaten atau kota.145 Sedangkan posisi masyarakat yang direpresentasikan dalam bentuk organisasi olahraga, hanya sebagai pelengkap dalam arti membantu peran negara.

Dalam Pasal 12 ayat (1) Undang-Undang Nomor 3 Tahun 2005 tentang Sistem Keolahragaan Nasional secara tegas dinyatakan bahwa "pemerintah mempunyai tugas menetapkan dan melaksanakan kebijakan serta standarisasi bidang keolahragaan secara nasional". Tugas ini kemudian diperbesar melalui Pasal 2 Peraturan Pemerintah Nomor 16 Tahun 2007 tentang Penyelenggaraan Keolahragaan. Pemerintah menentukan kebijakan nasional keolahragaan, standar nasional keolahragaan, serta koordinasi dan pengawasan terhadap penyelenggaraan keolahragaan nasional. Sedangkan penentuan kebijakan nasional keolahragaan, standar nasional keolahragaan, serta koordinasi dan pengawasan terhadap penyelenggaraan keolahragaan nasional menjadi tanggung jawab Menteri. Kewenangan yang diberikan Undang-Undang Nomor 3 Tahun 2005 tentang Sistem Keolahragaan Nasional kepada negara, yaitu kewenangan untuk mengatur, membina, mengembangkan, melaksanakan dan mengawasi penyelenggaraan keolahragaan didistribusikan kepada masyarakat. Peran masyarakat atau society dirumuskan secara tegas dalam Pasal 75 UndangUndang Nomor 3 Tahun 2005 tentang Sistem Keolahragaan Nasional, sebagai berikut:

(1) Masyarakat memiliki kesempatan yang sama dan seluasluasnya untuk berperan serta dalam kegiatan keolahragaan.

(2) Peran serta masyarakat sebagaimana dimaksud pada ayat (1) dapat dilakukan secara perseorangan, kelompok, keluarga, organisasi profesi, badan usaha, atau organisasi kemasyarakatan lain sesuai dengan prinsip keterbukaan dan kemitraan.

(3) Masyarakat dapat berperan sebagai sumber, pelaksana, tenaga sukarela, penggerak, pengguna hasil, dan/atau pelayanan kegiatan olahraga.

(4) Masyarakat ikut serta mendorong upaya pembinaan dan pengembangan keolahragaan.

Peran serta masyarakat ini diwujudkan juga dalam hal pengelolaan keolahragaan sebagaimana dirumuskan dalam Pasal 35, Pasal 36, Pasal 37, Pasal 38, Pasal 39, dan Pasal 40 Undang-Undang Nomor 3 Tahun 2005 tentang Sistem Keolahragaan Nasional, tetapi 


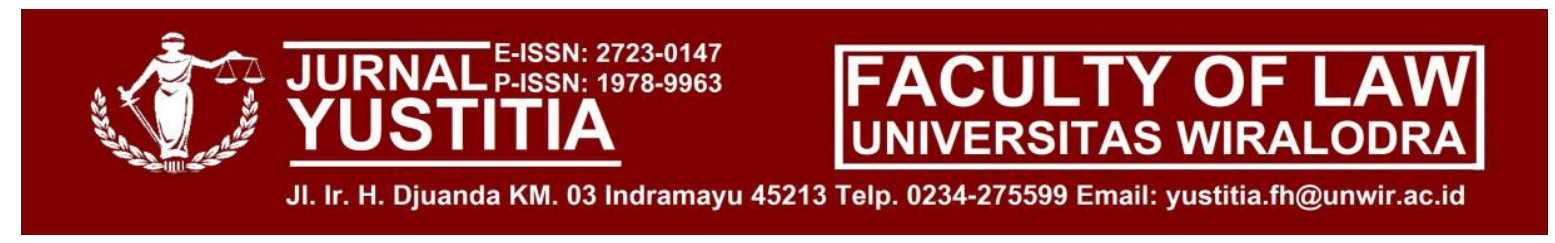

tetap dalam konteks diatur dan diawasi oleh negara. Artinya posisi masyarakat adalah sebagai bagian dari negara yang berfungsi membantu sebagian kecil urusan keolahragaan.

Dalam pengelolaan keolahragaan, masyarakat dapat membentuk induk organisasi cabang olahraga. Kemudian induk organisasi cabang olahraga ini membentuk suatu komite olahraga nasional. Pengorganisasian komite olahraga nasional ini ditetapkan oleh masyarakat yang bersangkutan sesuai dengan peraturan perundang-undangan dan bersifat mandiri. Komite olahraga nasional mempunyai tugas: ${ }^{42}$

a. membantu Pemerintah dalam membuat kebijakan nasional dalam bidang pengelolaan, pembinaan, dan pengembangan olahraga prestasi pada tingkat nasional;

b. mengoordinasikan induk organisasi cabang olahraga, organisasi olahraga fungsional, serta komite olahraga provinsi dan komite olahraga kabupaten/kota;

c. melaksanakan pengelolaan, pembinaan, dan pengembangan olahraga prestasi berdasarkan kewenangannya; dan

d. melaksanakan dan mengoordinasikan kegiatan multikejuaraan olahraga tingkat nasional.

Dalam perihal pengakuan negara atas keberadaan dari organisasi olahraga di Indonesia, dijelaskan di dalam Pasal 29 Undang-Undang No 3 Tahun 2005 tentang Sistem Keolahragaan Nasional, yaitu "Pembinaan dan pengembangan olahraga professional dilakukan oleh induk organisasi cabang olahraga dan/atau organisasi olahraga professional, yang dilaksanakan dan diarahkan untuk terciptanya prestasi olahraga, lapangan kerja, dan peningkatan pendapatan."Ketentuan Pasal tersebut merupakan bentuk pengakuan dari negara terhadap organisasi olahraga. Dalam hal ini maka negara Republik Indonesia mendistribusikan dua kewenangannya secara terbatas untuk melakukan pembinaan dan pengembangan, tetapi tiga dari lima kewenangan lainnya yaitu untuk mengatur, mengawasi dan melaksanakan tetap berada di tangan negara. Meskipun negara memberikan dua kewenangan yaitu membina dan mengembangkan kepada organisasi olahraga namun tetap diikat dengan sangat kuat melalui ketentuan Pasal 37 Peraturan Pemerintah Nomor 16 Tahun 2007 tentang Penyelenggaraan Keolahragaan.

\footnotetext{
${ }^{42}$ Pasal 35 ayat (1) Undang-Undang tentang Sistem Keolahragaan Nasional
} 
Menteri bertanggung jawab terhadap pembinaan dan pengembangan serta pengawasan dan pengendalian olahraga profesional. Dalam melaksanakan tanggung jawabnya menteri dibantu oleh Badan Olahraga Profesional pada tingkat nasional. Badan sebagaimana dimaksud mempunyai tugas:

a. menetapkan kebijakan pembinaan dan pengembangan serta pengawasan dan pengendalian olahraga profesional;

b. melakukan pembinaan dan pengembangan serta pengawasan dan pengendalian terhadap penyelenggaraan kegiatan olahraga profesional; Universitas Indonesia

c. melakukan pengkajian dan pengembangan sistem pembinaan dan pengembangan serta pengawasan dan pengendalian olahraga profesional; dan

d. menetapkan standar, norma, prosedur, dan kriteria pembinaan dan pengembangan serta pengawasan dan pengendalian olahraga profesional.

Selain hal tersebut, intervensi negara juga berjalan terlalu jauh bahkan mencampuri urusan olahraga yang menjadi domain Lex Sportiva dan Lex Ludica, yaitu pada Pasal 57 ayat (2) Peraturan Pemerintah Nomor 16 Tahun 2007 tentang Penyelenggaraan Keolahragaan yang mengatur alih status olahragawan amatir menjadi olahragawan professional, yaitu "Alih status olahragawan amatir menjadi olahragawan profesional wajib memenuhi persyaratan:"

a) memenuhi batasan usia sesuai ketentuan induk organisasi cabang olahraga atau federasi olahraga internasional;

b) dalam keadaan sehat jasmani dan rohani berdasarkan keterangan dokter yang ditunjuk oleh Badan Olah Raga Profesional;

c) pernah menjadi anggota perkumpulan olahraga amatir;

d) pernah mewakili Indonesia dalam Olimpiade, Pekan Olahraga Internasional Tingkat Asia (Asian Games), Pekan Olahraga Internasional Tingkat Asia Tenggara (South East Asian Games), kejuaraan olahraga tingkat dunia/internasional, menjadi juara nasional, atau menjadi juara tingkat provinsi; dan

e) mendapat rekomendasi dari induk organisasi cabang olahraga.

c. Kedudukan Menteri Pemuda dan Olahraga Republik Indonesia Terhadap Masalah Internal PSSI 


\section{TURNASN: 2723-0147}

Intervensi yang dilakukan Mentri Pemuda dan Olahraga dalam masalah internal PSSI

adalah ketika adanya kisruh perihal pemilihan Ketua Umum Periode 2011-2015. Ketika kisruh tersebut tidak kunjung selesai, Menteri Pemuda dan Olahraga mulai turut campur terhadap masalah tersebut. Dalam pernyataannya, dia mendesak agar PSSI melakukan koreksi dalam penyelenggaraan kongres empat tahunan. Dasar hukum dari pernyataan tersebut adalah dengan adanya Pasal 13 Undang-Undang Nomor 3 Tahun 2005 tentang Sistem Keolahragaan Nasional yaitu, "pemerintah mempunyai kewenangan untuk mengatur, membina, mengembangkan, melaksanakan dan mengawasi penyelenggaraan keolahragaan secara nasional."

Ketentuan pengawasan bahkan diatur lebih lanjut di dalam Pasal 118 Peraturan Pemerintah Nomor 16 Tahun 2007 tentang Penyelenggaraan Keolahragaan, yaitu: pengawasan yang dimaksud meliputi pengendalian internal dilakukan dengan cara memantau, mengevaluasi, dan menilai unsur kebijakan, prosedur, pengorganisasian, personil, perencanaan, penganggaran, pelaporan dan supervisi dari penyelenggara kegiatan keolahragaan.

Apabila kita melihat masalah ini, tindakan yang dilakukan oleh Menteri Pemuda dan Olahraga banyak dinilai sudah terlalu jauh, walaupun pada perkembangannya pemerintah menyatakan tidak akan campur tangan lagi terkait masalah pemilihan Ketua Umum PSSI ini berdasarkan dari pernyataan Presiden Susilo Bambang Yudhoyono, dimana beliau menyatakan "Saya pikir pemerintah tidak harus selalu ikut campur tangan, kita harus memberi kehormatan kepada PSSI untuk melakukan tugasnya sekarang, apabila ada konflik, ada Statuta dari FIFA untuk menyelesaikannya".159 Berdasarkan pernyataan tersebut terlihat adanya pengakuan negara terhadap ketentuan hukum dari FIFA mengenai penyelenggaraan kegiatan sepak bola di negara ini, namun kejadian ini tetap menyimpan suatu masalah hukum karena adanya ketentuan hukum yang memungkinkan pemerintah untuk melakukan intervensi terhadap masalah internal PSSI seperti yang dijelaskan sebelumnya. Kejadian ini menjadi suatu masalah karena apa yang diintervensi ini sudah meliputi ranah internal organisasi PSSI itu sendiri. Apabila kita lihat mengenai pembahasan tentang kedudukan organisasi PSSI di Indonesia, sudah jelas bahwa PSSI bukanlah organisasi dibawah pemerintah, sehingga dengan statusnya yang berupa organisasi olahraga yang mempunyai kedudukan sebagai badan hukum maka berarti pemerintah tidak bisa 
begitu saja ikut campur atas apa yang terjadi di dalam internal kepengurusan organisasi PSSI itu sendiri.

Dalam masalah ini, pemerintah memang mempunyai kewenangan dalam bidang olahraga, namun apabila kewenangan itu sampai pada turut campur terhadap masalah internal organisasi yang independen maka bisa dikatakan bahwa pemerintah telah melakukan suatu bentuk intervensi yang bersifat campur tangan. Dalam peraturan PSSI sendiri apabila ada suatu masalah sengketa di dalam tubuh organisasi mereka sendiri, mereka mempunyai metode penyelesaian sengketa tanpa perlu adanya intervensi dari pemerintah untuk menyelesaikan masalah tersebut, sehingga dengan ini tindakan pemerintah tersebut mengindikasikan bahwa pemerintah tidak menghormati suatu proses hukum dan aturan yang ada dan berlaku terhadap organisasi PSSI itu sendiri.

Sebagai satu-satunya organisasi sepak bola nasional di wilayah hukum Negara Kesatuan Republik Indonesia, Persatuan Sepak Bola Seluruh Indonesia pun memiliki kewenangan yang sama seperti FIFA, dalam lingkup negara Indonesia, termasuk untuk mendesain sistem peradilannya dalam rangka menyelesaikan sengketa sepak bola nasional. Desain sistem peradilan yang dituangkan PSSI dalam Statuta PSSI, tak ubahnya seperti menerjemahkan FIFA Statutes ke dalam bahasa Indonesia. Mereka pun memiliki Komisi Disiplin, Komisi Banding, dan Komisi Etika seperti halnya FIFA yang memiliki Disciplinary Committee, Appeal Committee, dan Ethics Committee. Hanya saja dalam Statuta PSSI, mereka kemudian memperkenalkan sebuah badan arbitrase yang menangani semua perselisihan dalam lingkup organisasi PSSI. Satu hal yang menarik adalah dalam Statuta PSSI tersebut, dinyatakan secara jelas pada Pasal 70 ayat (1), yaituPSSI, Anggota, Pemain, Ofisial, serta agen pemain dan agen pertandingan tidak diperkenankan mengajukan perselisihan ke Pengadilan Negara dan badan arbitrase lainnya serta alternatif penyelesaian sengketa lainnya, kecuali yang ditentukan dalam Statuta PSSI dan peraturan-peraturan FIFA dan setiap sengketa harus diajukan kepada yurisdiksi FIFA atau PSSI.

Selain itu, dalam menangani sengketa nasional, PSSI bisa menggunakan arbitrase dalam rangka penyelesaian sengeketa, seperti yang diatur di dalam Pasal 69 Statuta PSSI, PSSI memperkenalkan sebuah badan arbitrase yang bukan merupakan bagian dari badan peradilan yang dimilikinya. Dikatakan dalam Pasal 69 Statuta PSSI, yaitu PSSI mengadakan suatu Badan Arbitrase yang menangani semua perselisihan internal nasional antara PSSI, anggota-anggotanya, pemain-pemain, petugas dan pertandingan serta agen pemain yang 
tidak berada di bawah kewenangan badan-badan hukumnya. Mengenai kewenangan, komposisi, dan peraturan prosedur mengenai persidangan arbitrase ini masih akan diatur lebih lanjut oleh Komite Eksekutif PSSI melalui peraturan-peraturannya.

\section{PENUTUP}

\section{A. Simpulan}

Berstatus dengan statusnya sebagai organisasi bentukan masyarakat maka PSSI bukanlah sebagai bagian dari badan eksekutif pemerintahan indonesia. Sehingga kedudukan pemerintahan terhadap PSSI bukanlah suatu hubungan atasan dan bawahan, melainkan suatu hubungan kerja sama yang sejajar kedudukannya dalam menyelenggarakan kegiatan sepak bola di Indonesia.

1. Pertentangan yang terjadi antara sistem hukum nasional dengan sistem hukum FIFA dapat dilihat di dalam Pasal 118 Peraturan Pemerintah Nomor 16 Tahun 2007 tentang Penyelenggaraan Keolahragaan, di dalam pasal ini memberikan suatu celah bagi pemerintah untuk melakukan suatu intervensi terhadap masalah internal PSSI itu sendiri, sedangkan di dalam ketentuan statuta FIFA tidak diperbolehkan adanya campur tangan dari pihak lain dalam organisasi anggota dari FIFA. Selain itu, di dalam Undang-Undang Nomor 3 Tahun 2005 dan Peraturan Pemerintah Nomor 16 Tahun 2007 juga memberikan posisi pemerintah sangatlah dominan, seharusnya dijelaskan juga adanya suatu hubungan kerja sama yang sejajar antara organisasi olahraga di Indonesia dengan pemerintah dalam penyelenggaraan olahraga di Indonesia.

\section{B. Saran}

1. Pemerintah perlu mengadakan revisi terhadap undang-undang penyelenggaraan olahraga, karena undang-undang tersebut dinilai terlalu dominannya posisi pemerintah, sedangkan organisasi-organisasi olahraga yang ada sudah mempunyai peraturan tersendiri mengenai penyelenggaraan olahraga. Sehingga perlu diatur lebih lanjut mengenai koordinasi antara keduanya agar pembagian kewenangannya lebih jelas dan tidak menimbulkan konfilk, terutama Pasal 118 Peraturan Pemerintah Nomor 16 Tahun 2007 tentang Penyelenggaraan Keolahragaan yang memberikan suatu celah bagi pemerintah untuk melakukan intervensi pada organisasi olahraga di Indonesia. 
2. Mengingat adanya hukum FIFA yang berlaku di dalam penyelenggaraan sepak bola di seluruh negara, maka negara perlu melakukan pembatasan intervensi terhadap penyelenggaraan sepak bola di Indonesia. Pembatasan intervensi ini diberlakukan terhadap adanya intervensi yang bersifat campur tangan, sehingga intervensi yang bisa dilakukan pemerintah hanyalah dalam bentuk suatu kerja sama dengan PSSI dalam menyelenggarakan sepak bola di Indonesia.

\section{DAFTAR PUSTAKA}

\section{A. Buku :}

Bagir Manan, Lembaga Kepresidenan, cet. Ke 2 (Yogyakarta: FH UII Press, 2003)

Hinca Pandjaitan, Kedaulatan Negara vs Kedaulatan FIFA Dalam Kompetisi Sepakbola Profesional untuk Memajukan Kesejahteraan Umum, (Jakarta: PT Gramedia Pustaka Utama, 2011

Jimly Asshidiqie, Pokok-Pokok Hukum Tata Negara Indonesia (Pasca Reformasi), cet.

Ke 2, (Jakarta: PT Bhuana Ilmu Populer, 2008)

C. .T. Kansil dan Christine S.T Kansil, Hukum, Tata Negara Republik Indonesia 1 cet. Ke 3, (Jakarta: PT Rineka Cipta, 2000)

Purnadi Purbacaraka dan Soerjono Soekanto, Renungan Tentang Filsafat Hukum, (Jakarta: Rajawali, 1982)

Sondang Siagian, Administrasi Pembangunan, Konsep, Dimensi dan Strateginya, cet ke 4, Jakarta:

Yudha Bhakti Ardhiwisastra, Hukum Internasional, Bunga Rampai (Bandung: Alumni, 2003)

\section{B. Peraturan Perundang-Undangan}

Undang-Undang Dasar 1945.

Undang-Undang No. 3 Tahun 2005 tentang Sistem keolahragaan Nasional.

Peraturan Pemerintah No. 16 Tahun 2007 tentang Penyelenggaraan Keolahragaan.

Peraturan Pemerintah Nomor 17 Tahun 2007 tentang Penyelenggaraan Pekan dan Kejuaraan Olahraga.

Peraturan Pemerintah Nomor 18 Tahun 2007 tentang Pendanaan Olahraga. 